\title{
MORPHOMETRY OF TRACHEIDS OF Pinus taeda L. FROM A PRUNING TEST IN NE ARGENTINA.
}

\author{
Rosa Angela Winck ${ }^{1 *}$, María Isabel Martínez ${ }^{2}$, Elianne Itatí Romberg ${ }^{2}$, Hugo Enrique Fassola ${ }^{3}$, Diego Rolando \\ Aquino $^{4}$ Alicia Violeta Bohren ${ }^{5}$ \\ ${ }^{1 *}$ Nacional Institute of Agropecuary Technology, Wood Technology Area Researcher and National University of Misiones Professor, \\ Montecarlo, Misiones, Argentina - winck.rosa@inta.gob.ar \\ ${ }^{2}$ National University of Misiones, Nacional Forest Sciences Faculty, Forest Engineering, Eldorado, Misiones, Argentina - \\ marumarti.88@gmail.com, eir487@gmail.com \\ ${ }^{3}$ National Institute of Agropecuary Technology, National Coordinator of Forest Program and Forestry and Management Area Researcher, \\ Montecarlo, Misiones, Argentina - fassola.hugo@inta.gob.ar \\ ${ }^{4}$ National Institute of Agropecuary Technology, Support Technician, Montecarlo, Misiones, Argentina - aquino.diego@inta.gob.ar \\ ${ }^{5}$ National University of Misiones, Senior Lecturer of Wood Anatomy of Forest Sciences Faculty, Eldorado, Misiones, Argentina - \\ alicia@facfor.unam.edu.ar
}

Received for publication: 23/05/2018 - Accepted for publication: 14/10/2018

\begin{abstract}
Resumo
Morfometría de traqueídes de Pinus taeda L de um ensaio de poda en NE da Argentina. A região nordeste da Argentina e caracterizada por possuir plantações florestais de crescimento rápido, entre elas, Pinus taeda. $\mathrm{O}$ objetivo deste estudo foi avaliar a influência da poda e da estrutura vertical das arvores sobre as características morfométricas de traqueídes da árvore. Foram avaliadas 18 árvores de 16 anos de idade, obtidos de um ensaio de silvicultura, com densidade inicial de 1660 plantas / ha, sem desbaste, três tratamentos de poda, com remoção de $0 \%, 50 \%$ e $70 \%$ da copa verde da árvore, pertencendo aos estratos dominantes, codominantes e suprimidos. As amostras foram tomadas a uma altura de $1,3 \mathrm{~m}$, foram preparadas as fatias que foram observadas e medidas ao microscópio com uma câmara acoplada. Os dados foram analisados com modelos lineares mistos. A poda não influenciou a largura e no comprimento de traqueídes, mas afetou a espessura da parede celular, que disminuiu com o aumento da intensidade da poda. Enquanto a estrutura vertical das arvores (estrato) teve influência significativa no comprimento dos traqueoides, obtendo valores superiores para o estrato dominante, seguido pelo codominante e suprimido. A largura e espessura da parede celular não foram afetadas pelo estrato. Independentemente de pertencer ao estrato dominante, codominante ou suprimido, o comprimento de traqueídes apresentou um padrão crescente da medula para o córtex, com os valores mais baixos próximos à medula.
\end{abstract}

Palavras-chave: anatomia de traqueídes, qualidade da madeira, poda, estrutura vertical do povoamento.

\section{Abstract}

The northeast region of Argentina is characterized by fast-growing forest plantations, Pinus taeda among them. The objective of this study was to evaluate the influence of pruning and stand structure on the morphometric characteristics of tree tracheids. We evaluated 18 trees of 16 years old, from a silvicultural stand essay, with 1660 plants/ha as initial density, without thinning, three pruning treatments $0 \%, 50 \%$ and $70 \%$ removal of the green crown belong to the dominant, codominant and suppressed strata. Tree slices were taken at $1.3 \mathrm{~m}$ height, the conditioned samples were observed and measured with a microscope with digital camera. The data was analyzed using mixed linear models. Pruning did not have effect on the width and length of tracheids, but it affected to the cell wall thickness, which decreased with increasing pruning intensity. While the social position (stratum) had significant influences on the length of tracheids, given greater for individual in dominant stratum, followed by codominant and suppressed stratum. The cell wall width and thickness were not affected by the stratum. Regardless of the social position in the stand, the tracheid's length showed an increasing pattern from pith to bark with the lower values near to the pith.

Key words: tracheids anatomy, wood quality, pruning, stand vertical structure

\section{INTRODUCTION}

Northeast region of Argentina is characterized by the cultivation of forest species of fast growth aiming to support different wood markets. In this direction, Pinus taeda constitutes one of the highest important species, due to its high growth rate and extended planted surface. In Mesopotamia, it presents the highest concentrations of cultivated forests where there is predominance of conifer trees (83\%), fundamentally Pinus elliottii and Pinus taeda with cultivated surface of 639,135.95 hectares (MINISTERIO DE AGRICULTURA, GANADERÍA Y

FLORESTA, Curitiba, PR, v. 49, n. 3, p. 503 - 512, jul/set 2019

Winck, R. A. et.al.

ISSN eletrônico 1982-4688

DOI: $10.5380 /$ rf.v49 i3.59546 
PESCA, 2017).

Nowadays, wood is widely used for different industrial uses. Nevertheless, among the different activities that use it as raw material, the construction sector is one of the most demanding in terms of physical, mechanical, aesthetical and anatomical properties (ROCHA et al., 2015). This generates the need to evaluate raw material quality and to verify if it is applied the proper forest management type to the expected results.

The knowledge of the factors that influence wood quality is significant to optimize plantations' value and to improve companies' competitiveness. In order to do so, the incorporation of new characteristics that are representative of wood aptitude according to its final use must be aimed. In this direction, anatomical characteristics are intimately related to wood properties and, therefore, to its technological processing. In several applications, the requirements relate not only to physicomechanical properties adequate values but also to characteristics of wood fibres, homogeneity and the relation to other properties.

Wood properties affect derived products quality, which is specially right to the length of tracheids (KAMALA y MISSANJO, 2017). These authors determined that this variable relates strongly to the elasticity modulus and that, therefore, in order to improve wood flexion properties, tracheids' length is a factor to consider.

In a conifer, tracheid length increase usually is accompanied of S2 layer microfibre's angle diminution (MOLIŃSKI et al., 2008; LASSERRE et al., 2009). Donaldson (2008) and Oladi et al., (2017), found a strong and negative relation between tracheid's length and microfibre's angle. Also, other studies demonstrate that sound propagation speed along the fibres is strongly related to the length of anatomical elements (FABISIAK et al., 2010; FABISIAK et al., 2012). This variable as well is important in the paper industry; paper torn resistance increases with tracheids' length. On the other hand, short tracheids, flexible with thin walls collapse easily in industrial process and produce high-quality papers with excellent framework, with dense fibre covers and smooth surface, granting flexibility and resistance. Thick cell walls grant little tensile force, low bending resistance, but high tearing resistance (PEÑA-ALONSO, 2011). The cell wall thickness and length of tracheids are directly related to physicalmechanical and technological properties and they are fundamental in final use definition. An adequate pruning can contribute to improving log characteristics, however, Winck et al., (2013) determined that pruning did not affect tracheids' length of material from an intensity pruning test.

Tracheids' length also varies according to the individual's sociological position, dominant layer trees reach greater lengths, followed by codominant ones and suppressed ones (WINCK et al., 2013).

Cell wall thickness and tracheids' length are relevant attributes due to their influence in paper quality and with less impact on wood quality for sawmill. Its width is a variable parameter along its length and it is not used with diagnostic value (MARJA-SISKO, 1994).

There are researches about the influence of forest treatments regarding physical and mechanical properties, while in fibre level they are limited. Recently Winck et al., (2013) and Winck et al., (2015) have started anatomical characterization studies of Pinus taeda cultivated in the region. Moreover, it is not clarified the impact of pruning on wood fibres quality. This study hypothesis is that pruning intensity and tree diameter cause variation in cell wall thickness, width and length fo tracheids. The objective was to evaluate the effect of pruning and morphometric stratum intensity of tracheids from 16-year-old Pinus taeda wood and its length in radial direction at 1.3 meters high.

\section{MATERIALS AND METHODS}

The used material was obtained from a forest test of Pinus taeda $\mathrm{L}$. with distinct thinning and pruning intensities and opportunities, installed in a field in a randomized block design (FASSOLA et al., 2002), located at $56^{\circ} 01^{\prime} \mathrm{W}$ latitude and $28^{\circ} 24^{\prime} \mathrm{S}$ longitude, next to Santo Tomé city, in Corrientes province. The test was settled in 1996 when the plantation was 3 years old. The initial plantation density was 1660 plants per hectare. In this study, it was considered plots without thinning and with two pruning intensities. Pruning was applied at 3,4 and 5 years. The treatments were constituted by the witness treatment, without pruning (T1), as well as treatments with 50\% (T2) and 70\% (T3) of green crop removal, carried out in 3 highlights one year away from each other 18 trees were cut, 6 of each treatment, among each one 2 trees were selected for stractum, supressed (S), codominants (CD), dominants (D) (KÖHL et al., 2006). In table 1, it is presented stands' state variables in the moment of tree logging.

Tabla 1: Variável de estado do povoamento de Pinus taeda por tratamento, a os 16 anos de idade.

Table 1: Pinus taeda stands state variables by treatment at 16 years of age. 


\begin{tabular}{lcccccccccc}
\hline Treat & $\begin{array}{c}\text { Tree/ha } \\
(\mathbf{n} .)\end{array}$ & $\begin{array}{c}\mathbf{d h b} \\
(\mathbf{c m})\end{array}$ & $\begin{array}{c}\mathbf{d b h} \\
\mathbf{m a x} . \\
\mathbf{( c m})\end{array}$ & $\begin{array}{c}\mathbf{d b h} \\
\mathbf{m i n} \\
\mathbf{( c m})\end{array}$ & $\begin{array}{c}\mathbf{h} \\
(\mathbf{m})\end{array}$ & $\begin{array}{c}\text { hdom } \\
(\mathbf{m})\end{array}$ & $\begin{array}{c}\text { ph } \\
(\mathbf{m})\end{array}$ & $\begin{array}{c}\text { hbgc } \\
(\mathbf{m})\end{array}$ & $\begin{array}{c}\text { Enhancements } \\
(\mathbf{n} .)\end{array}$ & $\begin{array}{c}\text { Pruning } \\
\text { age } \\
(\mathbf{y e a r s})\end{array}$ \\
\hline $\mathrm{T} 1$ & 1111 & 26.4 & 39.8 & 18.3 & 25.4 & 26.2 & 0.0 & 19.5 & 0 & 0 \\
\hline $\mathrm{T} 2$ & 1055 & 26.1 & 39.5 & 15.6 & 25.5 & 26.9 & 7.0 & 19.9 & 3 & $3 ; 4 ; 5$ \\
\hline $\mathrm{T} 3$ & 833 & 26.5 & 34.0 & 16.2 & 24.7 & 26.1 & 6.4 & 18.9 & 3 & $3 ; 4 ; 5$ \\
\hline
\end{tabular}

Treat.: pruning treatment; T1: 0\% pruning, T2: 50\% pruning, T3: 70\% pruning; Tree/ha: number of trees per hectare, dbh: diameter at breast high; dbh max.: maximum diameter; dbh min: minimum diameter; h: tree average height; hdom: dominant height; ph: pruning height; hbgc: height until the base of green crop; Enhacements: number of pruning interventions.

It is well known that there is a variation of tracheids' morphometry according to tree height, it was considered that in order to capture the pruning effect it would be enough to take plump pruned samples. Therefore, from each $1.30 \mathrm{~m}$ height tree, a disk was obtained. A central $2 \mathrm{~m}$ wide piece of lumber was marked and the right radius was taken in order to separate growth rings. Each one was identified and then chipped and dissociated to measure tracheids' length as well as late wood width and thickness of the cell wall.

Growth rings were separated with a cutter, hammer, magnifying glass and jigsaw. After that, each sample was placed in test tubes, labeled with growth ring data, tree number and pruning treatment. The samples were placed in watery suspension at $80^{\circ} \mathrm{C}$ temperature for 48 hours in order to hydrate them. Then, fibres dissociation was carried out through Nuñez and Pavlik (1999) technique. After dissociation process, the samples were divided into two parts, one of them was used to measure width and length of tracheids with FQS (Fiber Quality Analyzer) team, the other one was submitted to staining process with safraning at $1 \%$, aiming at a better visualization of tracheids' cell wall. The samples were placed in a paper filter, on a funnel, in a beaker, submerging the sample for 20-30 $\mathrm{min}$ in the solution and repeating it 2-3 times. Finally, the samples were washed with water until the filtered liquid was transparent. Once the samples were dyed, they were placed in a slide, covering them with a cover glass.

Cell wall measurement was carried out in an optical microscope, connected to a camera with Motic Image Plus 2.0 software, following IAWA (1989) (International Association of Wood Anatomists) normative recommendations, that indicates to perform a minimum of 25 measurements of each sample. That is, growth ring from each late wood were taken from the 18 disks. In each tree, there were 15 rings. 18 trees*15rings $* 25$ repetition $=6750$ measurements in total for cell wall thickness.

For tracheids' length and width, 1000 measurements were carried out for each growth ring, that is $18 * 15 * 1000$ (trees-rings-repetitions $=270,000$ measurements of each variable).

Data were analyzed with ANOVA, through mixed generalized linear models using "InfoStat" software version of 2017. Mixed generalized linear models provide the possibility to analyze data with dependency, underbalance and lack of normality structure.

95\% level of confidence was used. For the response of variables: tracheids' length, width and thickness of cell wall the following factors were considered: pruning intensity, social position and growth rings and the interaction between factors. Averages comparison were carried out through DGC method (DI RIENZO et al., 2002). Tracheids' length equations for each social position were made through mixed generalized linear models analysis, age logarithm was used in order to increase adjust precision.

\section{RESULTS}

\section{Pruning intensity effect on tracheids' length}

Pruning treatments did not affect tracheids' length ( $\mathrm{p}$-value $=0.1572$, equal letters in Figure 1). Average values were $2833 \mu \mathrm{m}, 2756 \mu \mathrm{m}$ and $2729 \mu \mathrm{m}$ for the control sample, 50\% and $70 \%$ pruning, respectively. 


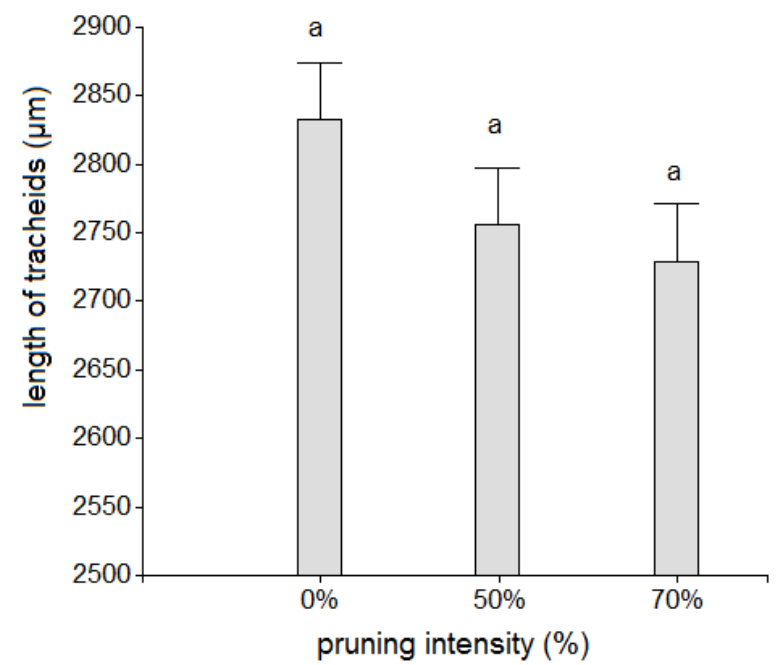

Figura 1: Comprimento medio de traqueídes para cada intensidad de poda.

Figure 1: Average length of tracheids for each pruning intensity.

\section{Social position effect in tracheids' length}

Tracheids' length varied according to the tree social position. Statistically significant differences were obtained ( $\mathrm{p}$-value $=0.0001$, different letters in Figure 2) for $95 \%$ confidence level for different social position. Average values for tracheids' length were $2550 \mu \mathrm{m}, 2759 \mu \mathrm{m}$ and $3010 \mu \mathrm{m}$ for suppressed, codominant and dominant trees, respectively.

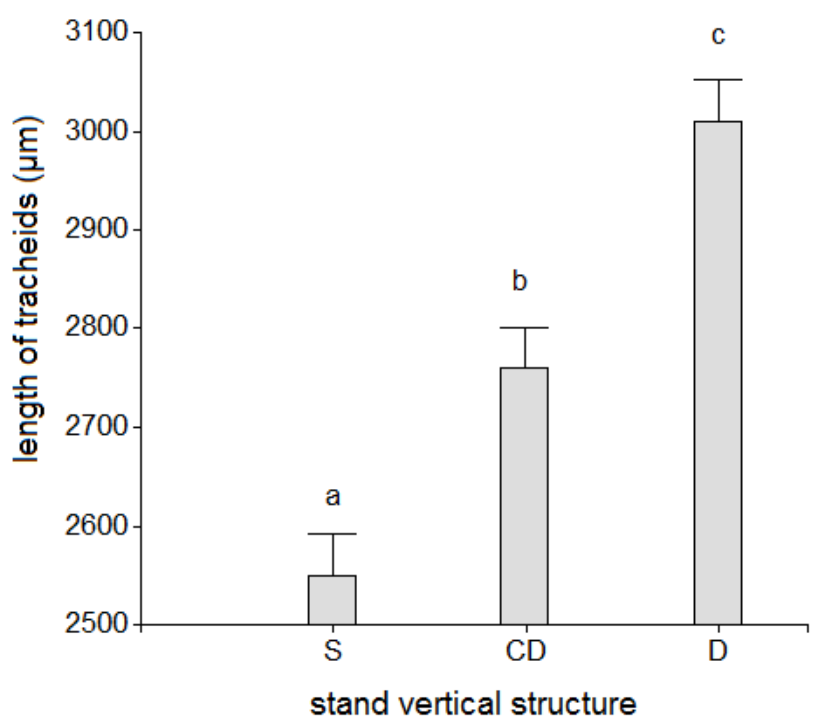

Figura 2: Comprimento medio de traqueídes para cada estrato.

Figure 2: Average length of tracheids for each stand vertical structure.

\section{Relation between tracheids' length average values at $1.3 \mathrm{~m}$ height and age.}

Equations obtained through regression analysis show a clear variation of length from the pith to the bark of the trees. Shorter tracheids in pith, which corresponds to a youthful wood, increasing until trunk periphery, with presence of mature wood, was observed.

The developed equations express the relation existing between tracheids' length and age logarithm for each social position. Coefficients of the models (1), (2) and (3) were 2188; 2066 and $1532 \mu \mathrm{m}$ for dominant, codominant and suppressed trees, respectively.

(1) length $_{D}=2188+458 * \ln ($ age $)$

(2) length $C D=2066+378 * \ln ($ age $)$ 
(3) length s $_{S}=1532+560 * \ln ($ age $)$

In which: length ${ }_{D}=$ Dominant trees' length of tracheids, length ${ }_{C D}=$ Codominant trees' length of tracheids, length $\mathrm{s}=$ Suppressed trees' length of tracheids. In= natural logarithm of age.

Average values found for tracheids length of dominant, codominant and suppressed trees, in relation to radial growth rings are presented in Figure 3. They indicate that this variable increased rapidly in the first 6 years, there is practically a linear increase, with deceleration between 7 and 11 years, presenting a smaller growth from this age on. It is also noted a bigger difference between tracheids' length values to dominant trees in relation to the others. Nevertheless, constant values were not reached, a reason why it is possible to assume that they did not reach maturity yet at 16 years old. On the other hand, it was verified that dominant trees' length of tracheids was superior to the codominant and suppressed trees during all tree growth stage (from 1 to 16 years). From this analysis, it is contrasted how social position is closely related to tracheids' length. Dominant trees presented higher values of length followed by codominant and suppressed trees independently of the pruning treatment they received. This behaviour occurred for each growth ring, accentuated according to age, in which 16 years old dominant trees the values surpass $3400 \mu \mathrm{m}$, while codominant and suppressed trees reach values about $3000 \mu \mathrm{m}$ (Figure 3).

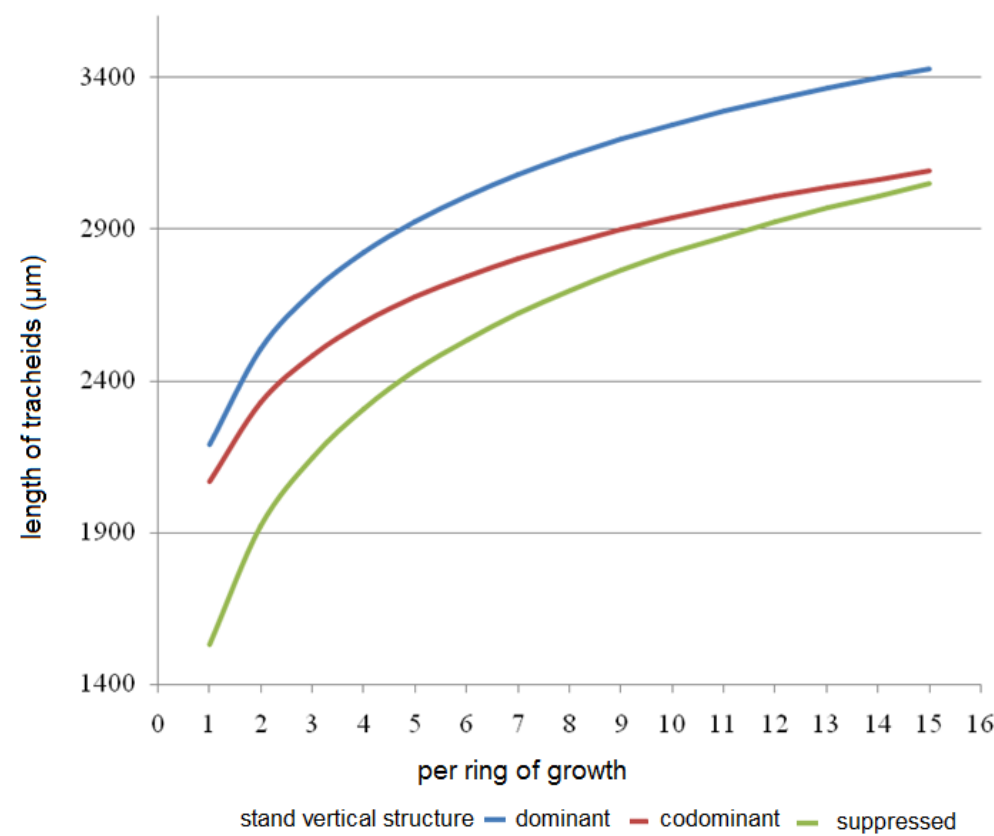

Figura 3: Variação radial do comprimento médio de traqueídes para cada anel de crescimento para cada estrato. Figure 3: Radial variation of the average length tracheids per ring of growth for each stand vertical structure.

Another important behaviour to highlight is that dominant trees reached higher values of tracheids' length at younger ages in relation to codominant and suppressed trees. Dominant trees reached $3000 \mu \mathrm{m}$ of tracheids' length after 6 years, while this length for codominant and suppressed trees was reached after 11 and 14 years respectively.

\section{Pruning intensity effect on tracheids' width}

In this analysis was possible to observe that pruning did not influence the results ( $\mathrm{p}$-value $=0.5336$, equal letters in Figure 4). Significant differences were not detected among the treatments. Values for cell wall width were $38.40 \mu \mathrm{m}, 39.27 \mu \mathrm{m}$ and $38.53 \mu \mathrm{m}$ for $0 \%, 50 \%$ and $70 \%$ pruning, respectively. (Figure 4). 


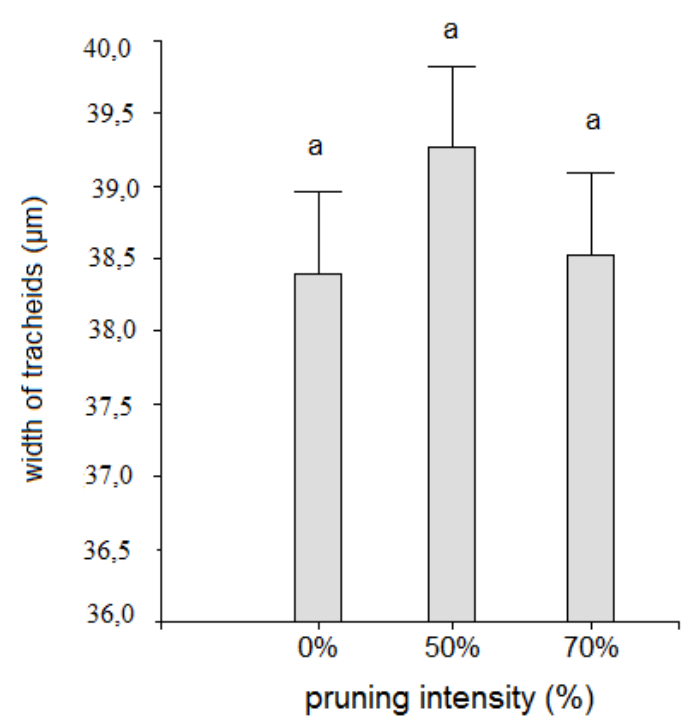

Figura 4: Largura media dos traqueídes para cada intensidad de poda. Figure 4: Average width of tracheids according to pruning intensity.

\section{Social position effect on tracheids' width}

Width of tracheids was not affected by trees' social position ( $\mathrm{p}$-vaue $=0.3027$, equal letters in Figure 5). Average values for tracheids' were $38.55 \mu \mathrm{m}, 39.42 \mu \mathrm{m}$ and $38.21 \mu \mathrm{m}$ for suppressed, codominant and dominant trees, respectively (Figure 5).

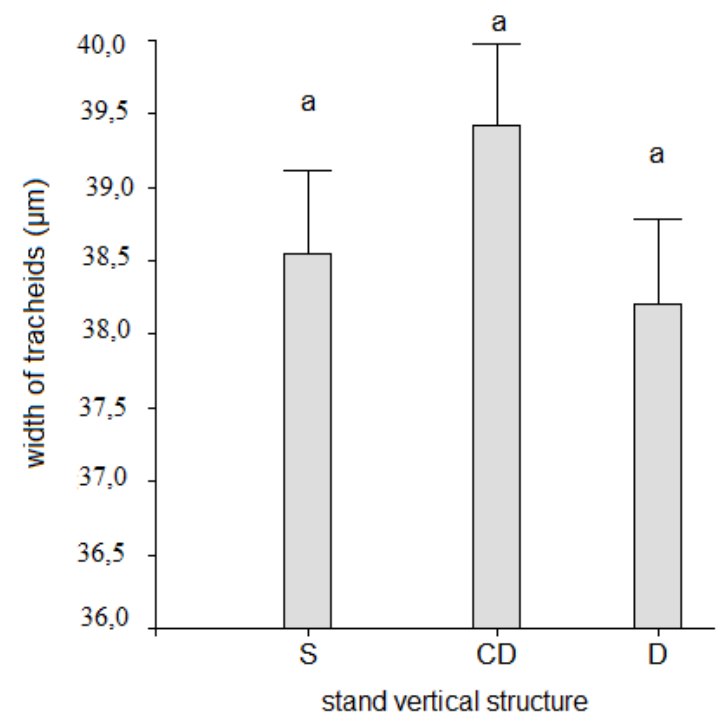

Figura 5: Largura media dos traqueídes para cada estrato.

Figure 5: Average width of tracheids according to stand vertical structure.

\section{Pruning intensity effect on cell wall thickness}

Cell wall thickness was affected by pruning intensity ( $p$-value $=0.0001$, different letters in Figure 6). Higher average values for cell wall thickness $(9.01 \mu \mathrm{m})$ were obtained for nonpruned trees. For treatments with $50 \%$ and $70 \%$ of pruning intensity, the values were $7.93 \mu \mathrm{m}$ and $7.25 \mu \mathrm{m}$, respectively (Figure 6). Cell wall thickness values decreased by $12 \%$ and $20 \%$ with the application of $50 \%$ and $70 \%$ of pruning, respectively. 


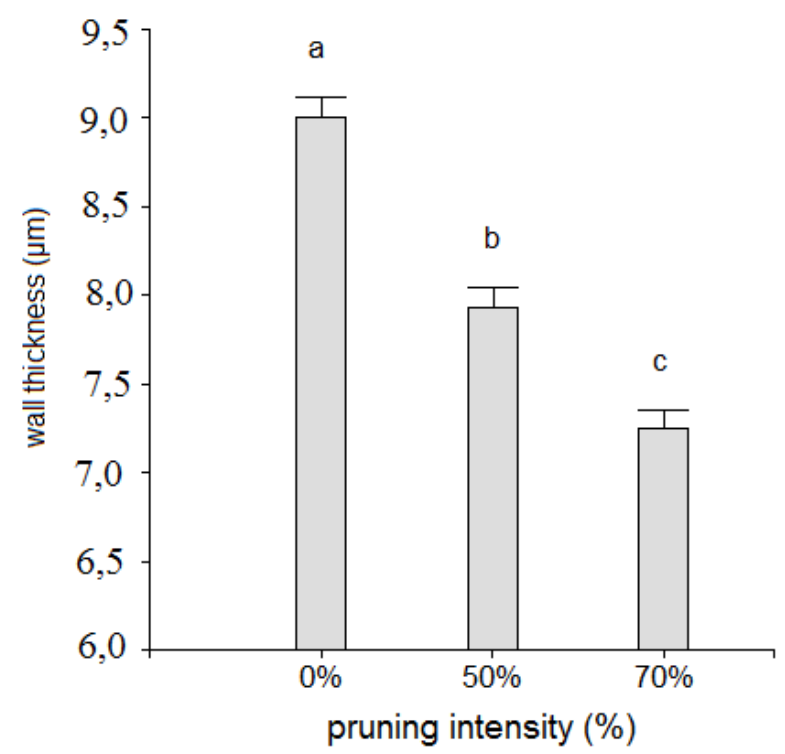

Figura 6: Espesor medio das paredes celulares dos traqueídes para cada intensidad de poda. Figure 6: Average wall thickness of tracheids for each pruning intensity.

\section{Social position effect on cell wall thickness}

As can be observed in Figure 7, different social position presented similar values for cell wall thickness, with no statistically significant differences ( $p$-value $=0.5729$, equal letters in Figure 7 ). It is possible to notice that cell wall thickness tend to decrease in relation to tree size, although this decrease is smaller than $2 \%$. values of $8.17 \mu \mathrm{m}, 8.07 \mu \mathrm{m}$ and $7.97 \mu \mathrm{m}$ for suppressed, codominant and dominant trees were registered, respectively.

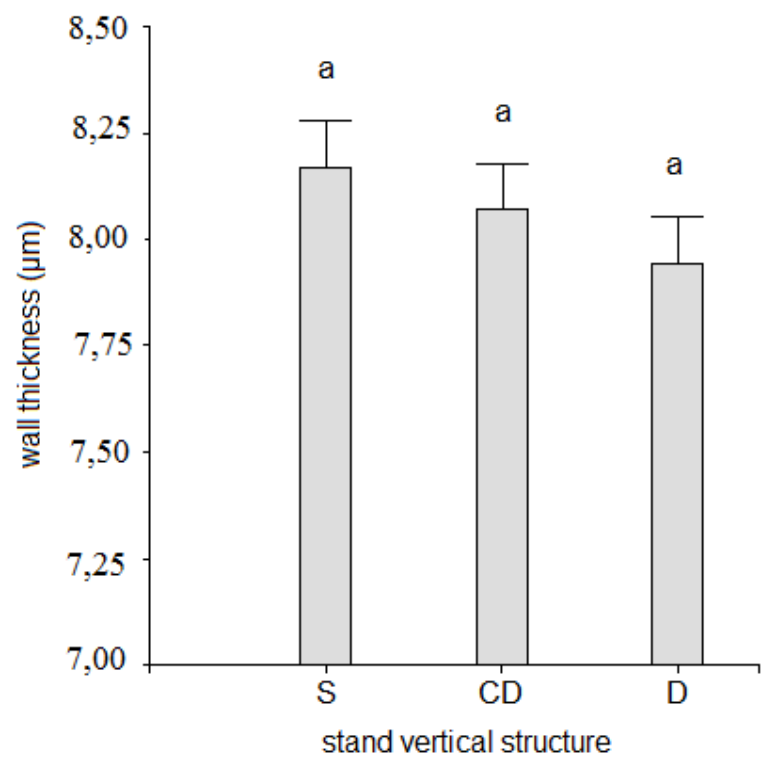

Figura 7: Espesor medio de parede celular dos traqueídes para cada estrato.

Figure 7: Average wall thickness of the tracheids for each stand vertical structure.

\section{DISCUSSION}

The generated information allowed the knowledge of wood's tracheids characteristics, which are important as much for solid products industries as for cellulose industry. Tracheids' length and cell wall thickness are closely related to wood resistance properties (WINCK, 2015) and, therefore, to its technological processing.

The average values determined in this study are similar to the ones found in Winck et al. (2013), in cambial age (at $3 \mathrm{~cm}$ from the bark). These results help decision making in the moment of pruning execution. In

FLORESTA, Curitiba, PR, v. 49, n. 3, p. 503 - 512, jul/set 2019

Winck, R. A. et.al.

ISSN eletrônico 1982-4688

DOI: $10.5380 /$ rf.v49 i3.59546 
this study, pruning did not stimulate a bigger growth of tracheids' length.

Therefore, if the final destination of the plantation were cellulose industry, the most common is not to execute this forest practice. However, if the raw material were destined for solid use, pruning provides other benefits, such as the obtention of bigger proportions of knot-free wood (MAKINEN et al., 2014) for "at sight uses".

Another pruning advantage is the facilitation of workers' and machines' movement in the plantation, it also contributes to prevention and control of forest fires (FASSOLA et al., 2002).

On the other hand, tracheids' length presented variations regarding the evaluated social position, agreeing with the behaviour obtained by Winck et al. (2013), who found tracheids' length values of $2698 \mu \mathrm{m}, 2333 \mu \mathrm{m}$ and $2184 \mu \mathrm{m}$ for dominant, codominant and suppressed trees, respectively.

Unlike this study, they worked with a compound sample (late and early wood) obtained at $1.30 \mathrm{~m}$ height and at $3 \mathrm{~cm}$ from the bark of 16 years old Pinus taeda wood. Also, Vivian et al. (2015), studying technological characteristics of 21 years old Pinus taeda wood destinated to cellulose industry, determine average values of 3500 $\mu \mathrm{m}$. On the other hand, in broadleaf species, they found a behaviour similar to the conifers. Trevisan et al. (2013), for Eucalyptus grandis determine for dominant trees higher values of fibres' length than in medium trees. Therefore, practices that provide tree development with a dominant character will favor the obtention of longer fibres, normally these individuals are characterized as presenting a genetic superiority. Also, the value of this variable improved according to the age of the tree, it improved from the pith to the bark, which is due to wood maturation and it agrees to the expressed by Fabisiak et al. (2014).

Tracheids' width was not affected by pruning treatment nor by tree social position. The average values obtained were similar to the ones found by Vivian et al. (2015), for the same species, these authors obtained an average value of $40.55 \mu \mathrm{m}$, whereas Nuñez (2008) determined for conifers values between 20 and $60 \mu \mathrm{m}$. Tracheids' width is a variable parameter along its length, and including in the same site, since it does not have a circular section, for that reason it is not used as a diagnostic value (MARJA-SISKO, 1994). Nevertheless, the relationship between fibre length and fibre diameter, known as felting coefficient, constitutes an indicator of paper resistance (HASSANKHANI et al., 2015). There are two ways to determine tracheids' width in wood tissues: by transversal cuts made with a microtome and in disintegrated ones. The measurements present different values presenting the highest tracheids' width values when they are obtained from disintegrated material, which is the case of this study. This is due to, on one hand, the tensioned wood cells which expand and delignify, and, on the other hand, in disintegrated ones the elements are collapsed due to their position and, to a certain extent, the pressure from the coverglass. For paper industry, it is recommended to measure tracheids' width in disintegrated material since it is how they will be found in a paper sheet and this way it is possible to compare them with cellulose compounds that can possibly be made.

Pruning intensity affected cell wall thickness value, however, social position had no influence. The average values found are superior to the ones determined by Vivian et al. (2015), who registered averages values of $6.41 \mu \mathrm{m}$ for a 21 years old Pinus taeda. A more intense pruning provided the development of thin walls tracheids. This has a negative impact on tracheids' cell wall thickness when the intention is to use the wood for solid purposes since it affects density and impacts its resistance. While it is a favorable characteristic when raw material destiny is paper industry, since short, flexible tracheids with thin cell walls collapse easily in industrial process and produce high-quality papers with frameworks of several unions, dense fibre coat, smooth surfaces and it emphasizes its flexibility and resistance. Thick cell walls grant little tensile force, low bending resistance, but high tearing resistance (PEÑA-ALONSO, 2011). That is, this "negative impact" for the aspects regarding mechanical properties for structural uses favors positively one of the final products of paper industry.

Depending on the final destiny of the tree, it would be interesting the use of big diameter individuals. Although, for industrial benefit, it would be greater the yield the sawn product. On the other hand, these units reached also bigger tracheids' length, which is beneficial as much for solid use as for paper industry. Moreover, it was verified that cell wall thickness decrease was not significant, it would no affect density and mechanical properties of wood, what is also beneficial for the lumber industry.

From the studied variables, tracheids' length suffered variations according to the social position of the tree and cell wall thickness due to pruning intensity, these are the variables that influence other wood properties, such as density and elasticity modulus. Lasserre et al. (2009), in a study about initial spacing influence on Pinus radiata wood properties, indicate a strong relationship between these two anatomical properties and mechanical and physical properties. They also point that cell wall width values are practically constant in radial direction, according to the age of the tree. These authors found an inverse relation between tracheids' length and microfibrillar angle, they affirm that both impact the technological properties of wood. Moreover, they indicate that there is a strong positive correlation between fibre length and specific conductivity. They sustain that with 
bigger fibre length it is reduced the quantity of times water must pass through the pit apertures, indicating an important physiological function of the plant. Due to the strong relationship found between fibre length and slenderness of the stem (relation diameter/height), they recommend managing such conditions in order to guarantee adaption and an adequate water flow, although they point the need to carry out a deeper research to confirm this mechanicist explanation.

Forest treatments have uncertain effects and in some cases contradictory about wood properties. Foster (2010) carried out a broad review about forest treatments' effects on wood properties, which indicate that pruning effect on tracheids' length is not very clear. On the other hand, the author mentions other studies, in which fibre length increased slightly after pruning. What was attributed to the reduction of youthful wood after branches' elimination. Nevertheless, the author also indicated other researches in which pruning had little or no effect on fibre's length. On the other hand, Makinen and Hynynen (2014) evaluated fertilization and thinning influence on tracheids' length of wild pine and concluded that these forest treatments improve considerably growth rate, but they do not cause damaging changes in wood properties and tracheids' length. Statistically significant differences in cell wall thickness between pruning intensity treatments would be indicating a variation in wood density, since cell wall proportion influences in this property value and therefore in its resistance.

Independently of the obtained result about pruning influence on tracheids' morphology, it is important to highlight that this forest treatment favors the obtention of quality wood, due to knots elimination, which is beneficial to all final uses of wood. Another pruning benefit is the manipulation of crop size, forcing its recession, inducing wood maturation and decreasing youthful wood proportion.

\section{CONCLUSIONS}

- Pruning intensity did not affect statistically the length and width of tracheids. Although cell wall thickness of tracheids was affected by pruning, the value for this variable decreases with pruning intensity. The most intense treatment, with $70 \%$ removal of green crop, was the most adequate regarding cellulose industry since the treatment obtained thin tracheids' cell walls.

- Tree's social position had no significative influence on cell walls' width and thickness, nevertheless, it affected length of tracheids, which was bigger for dominant trees, followed by codominant and suppressed ones.

- Cell wall's length and thickness of tracheids varied considerably from the pith to the bark, while the width was constant in a radial profile.

\section{ACKNOWLEDGEMENTS}

Se agradece al ingeniero Ernesto Héctor Crechi de la Estación Experimental Montecarlo y al ingeniero Rául Pezuttii de la Empresa Bosques del Plata S.A, quienes instalaron oportunamente el ensayo de poda y raleo. Además de permitir realizar la extracción de los árboles para realizar los estudios de calidad de madera. Al técnico Otto Knebel del Instituto Nacional de Tecnología Agropecuaria por su intensa colaboración en el apeo de los árboles y en el procesamiento de las muestras.

\section{REFERENCES}

DI RIENZO, J.A.; GUZMÁN, A.W.; CASANOVES, F. A Multiple Comparisons Method based on the Distribution of the Root Node Distance of a Binary Tree. Journal of Agricultural, Biological, and Environment Statistics, v.7, n.2, 2002, 14 p.

DONALDSON L. Microfibril angle: measurement, variation and relationships - a review. IAWA J. v.29, n.4, p. 345-386, 2008.

FABISIAK E., ČUNDERLIK I., MOLIŃSKI W. Ultrastructure and ultrasound wave propagation velocity in spruce (Picea abies L.) resonance wood. Ann. WULS - SGGW Forestry and Wood Technol. n.71, p. 170-176, 2010.

FABISIAK, E.; MOLIŃSKI, W.; KÚDELA, J.; MANIA, P. A study on the dependence between tracheid lengths and microfibril angle in resonant wood of spruce (Picea abies L.). Ann. WULS - SGGW. Forestry and Wood Technology. n.77, p. 222-226, 2012.

FABISIAK, E.; MANIA, P.; KÚDELA, J. Variation in tracheid lengths in resonance wood of spruce (Picea abies L.). Ann. WULS - SGGW. Forestry and Wood Technology. n.86, p. 104-108, 2014. 
FASSOLA, H.; MOSCOVICH, F.; FERRERE, P.; RODRÍGUEZ, F. Evolución de las principales variables de árboles de Pinus taeda L. sometidos a diferentes tratamientos silviculturales en el nordeste de la provincia de Corrientes, Argentina. Ciência Florestal, v.12, n.2, p. 51-60, 2002.

FOSTER, H.J. A review of the effects of silviculture on wood quality. 2010. <https://www.researchgate.net/publication/279692579>. Acceso 22 de mayo de 2018.

HASSANKHANI, M. BEHZAD KORD, B.; POURPASHA, M.M. Empirical statistical model for predicting wood properties of Paulownia fortunie. Part 1: physical and biometrical properties. Maderas. Ciencia y Tecnología. n.17, v.4, p. 919- 930, 2015.

INTERNATIONAL ASSOCIATION OF WOOD ANATOMY. List of microscopic features for hardwood identification. IAWA Bulletin, Utrecht, v.10, n.3, p. 219-332, 2002.

KAMALA, F.; MISSANJO, E. Radial and Among-Family Variations of Tracheid Length and the Relation ships with Bending Properties in Pinus patula. International Journal of Research in Agriculture and Forestry. v.4, n.11, p. 9-13, 2017.

KÖHL, M.; MAGNUSSEN, S.; MARCHETTI, M. Sampling Methods; Remote Sensing and GIS. Multiresource Forest Inventory. Ed. Springer. Berlin. Heidelberg. Serie Tropical Forestry, 2006, 388 p.

LASSERRE, J.P.; MASON, E.G.; WATT, M.S. Influence of initial planting spacing and genotype on microfibril angle, wood density, fibre properties and modulus of elasticity in Pinus radiate D. Don corewood. Forest Ecology and Management, n.258, p.1924-1931, 2009.

MINISTERIO DE AGRICULTURA, GANADERÍA Y PESCA (MAGyP) de Desarrollo Foresto Industrial. 2017.

MAKINEN, H., VERKASALO, E. and TUIMALA, A. Effects of pruning in Norway spruce on tree growth and grading. Forestry, v.87, p. 417-424, 2014.

MAKINEN, H. and HYNYNEN, J. Wood density and tracheid properties of Scots pine: responses to repeated fertilization and timing of the first commercial thinning. Forestry, v.87, p. 437-447, 2014.

MARJA-SISKO, I. Fiber atlas. Identification of papermaking fibers. T. E. Timell. New York. p.15-20, 1994.

MOLIŃSKI, W., FABISIAK, E., MARCINKOWSKA, A. Investigations on the relationships between the length of tracheids and the microfibril angle in the tangential walls of pine (Pinus sylvestris L.) wood tracheids. Proc. 4rd International of Wood with Various Forms of Energy. Sept. 9-11, Zvolen,: 1-8. 2008.

NUÑEZ, C. E. Pulpa y papel I. $4^{\text {ta }}$ parte. Anatomía de la Madera-Macro. p. 20-44, 2008.

NUÑEZ, C. E.; PAVLIK, C. A. Disgregado de tejidos leñosos por el método clorito- ácido acético-carbonato. Evaluación del daño producido a las fibras. Madera Ciencia y Tecnológica. v.2, n.2, p.33-37, 1999.

OLADI, R. POURTAHMASI, K. PARSAPAJOUH, D. Verifying the Preston equation betwen the average of tracheid length and microfibril angle in Cupressus ariizoniica compresion and oposite wood. Iranian Journal of Wood and Paper Industries, v.8, n.3, Autumn 2017.

PEÑA-ALONSO, J. R. Manual de histología vegetal. Paraninfo. Madrid. p. 240-241, 2011.

ROCHA, H. L. S.; PAES, J. B.; MINÁ, A. J. S.; OLIVEIRA, E. Caracterização físico mecânica da madeira de jurema-preta (Mimosa tenuiflora) visando seu emprego na indústria moveleira. Ciências Agrárias, Recife, v.10, n.2, p. 262-267, 2015.

TREVISAN, R.; SOUZA, J.T. DE; DENARDI, L.; HASELEIN, C.R.; SANTINI, E.J.. "Efeito do desbaste no comprimento das fibras da madeira de Eucalyptus grandis W. Hill ex Maiden”. Ciência Florestal, Santa Maria. n.23, v.2, p. 461-473, 2013.

VIVIAN, M.A.; SIMKUNAS SEGURA, T.E.; BONFATTI JÚNIOR, E.A.; SARTO, C.; SCHMIDT, F.; GOMES DA SILVA JÚNIOR, F. GABOV, K.; FARDIM, P. Qualidade das madeiras de Pinus taeda e Pinus sylvestris para a produção de polpa celulósica kraft. Scientia Forestalis, Piracicaba, v.43, n.105, p.183-191, 2015.

WINCK, R. A.; FASSOLA, H. E.; AREA, M. C.; PEZZUTTI, R. Relación entre la poda y la longitud de traqueidas en madera de Pinus taeda. 13er Congreso Internacional en Ciencia y Tecnología de Metalurgia y Materiales. Simposio internacional de materiales lignocelulósicos, Misiones, Argentina. 2013.

WINCK, R. A.; FASSOLA, H. E.; AREA, M.C. Efecto del raleo sobre las propiedades anatómicas de la madera de Pinus taeda. Madera Ciencia y Tecnología. v.17, n.8, p. 391-406, 2015. 